\title{
Modernization changes and economic stability of Russia during globalization of world economy
}

\author{
Andrey Novikov ${ }^{1, *}$ and Irina Zhulega ${ }^{2}$ \\ ${ }^{1}$ SPBU, Department of Economic Theory and Economic Policy, 191194, Saint Petersburg, Russia. \\ ${ }^{2}$ State University of Aerospace Instrumentation, Institute of Enterprinership Technologies, \\ Department of High-Tech Sistems Security, 190000, Saint Petersburg, Russia.
}

\begin{abstract}
Modernization is a special form of development of society, development of technology and economy is the cornerstone of modernization. However, this development is not evolutionary, but revolutionary, accompanied with rather fast institutional transformations. Besides, modernization should be considered as a problem which covers, first of all, the sphere of economy but which cannot be studied and solved without interaction practically with all directions of activity of the person and society. Modernization models taking into account mental and civilization features of Russia are analyzed. The changes connected with globalization changes in world economy and resistance to these changes of the Russian social and economic institutes are considered. Need of coordination of processes of social and economic transformations with set of informal institutes of the Russian society is emphasized. On the basis of the carried-out analysis the conclusion about existence of various ways of further economic development is drawn. Russian norms and traditions, being integrated with the chosen elements of the western institutional environment, will create conditions for sustained economic growth. Thus, transition to essentially new concept of economic development of the country will be made.
\end{abstract}

\section{Introduction}

In the context of modern globalization tendencies of the world economy, there is a need for social-political, economic and other transformations in individual national economies. In Russia, the need for such transformations is usually justified by the term "modernization", the understanding of which is ambiguous.

Modernization is most often understood as a change in accordance with the requirements of modernity, or amelioration, improvement, renovation of the object, bringing it into the line with new requirements and norms, specifications, quality indicators.

In this understanding, modernization appears as a problem solved by a certain formula, in which the emphasis is on the production and technological element: funds and resources

\footnotetext{
* Corresponding author: a-novikov08@mail.ru
} 
are extracted, technologies are bought and the problem is solved. However, modernization is not a task, but a problem, a problem that cannot be considered and solved without interaction with almost all spheres of human life and society.

This is a special form of development, which is based on the development of technology and the economy - not evolutionary, but revolutionary, accompanied by rather fast institutional transformations of one sort or another.

Thus, modernization is a comprehensive process of transformation, social-economic and technological revolution that changes all spheres of society. Modernization transformations in the economic and technological sphere are accompanied by changes in both formal and informal institutions in accordance with the requirements of the modern globalizing world economy.

\section{Background of globalization and modernization potential of Russian economy}

In the situation of the current world economic activity it is necessary to understand how to define requirements of the global economy, what impact can and should be expected when complying with these requirements, what the essence of "modernity" is, how its requirements will change in the future, and, most importantly, whether it is necessary to comply with these requirements or it is better to determine our own goals and find the right way for their early achievements. In addition, it is necessary to determine the correlation between the tendencies of globalization and deglobalization in the world economy.

According to historical experience, sooner or later, voluntarily or involuntarily, under the influence of changing natural or geopolitical factors, every state has to speed up the natural development of the economic and technological sphere (through the introduction of technical achievements, most often borrowed from neighbors) and at the same time compulsorily introduce new or modify old institutions of society, that is, to modernize. [1]

Having preserved their own civilization peculiarities from the invasions of the West, Russia (until the end of the seventeenth century), and Japan, China and Turkey (until the mid-nineteenth century) were forced to adopt the economic and technical inventions of the West, that is, the industrial system and everything that accompanies it, along with public and political institutions.

Thus, the focus was on a more technologically advanced and aggressive neighbour, whose social and economic condition set the very "requirements of modernity."

Since the rapid development of industry in Western Europe, Western civilization started to determine the "requirements of modernity" and "modernization" was understood as the desire to "be equal" to the West, which by virtue of obvious technological superiority over other nations actually imposed on them their idea of the image of civilizational existence [2]. After the World War II, the United States, which moved faster than anyone to the postindustrial economy and liberalism in the public sphere, were taken as a standard.

One of the leading theorists of modernization, Sh.N. Eisenstadt traces in his statements the idea that modernization is derived from the type of civilization which originated in Europe, and is the result of the evolution of Western European civilization, where democratic government and liberal economies are inherent: "Modernization ... should be considered as a specific type of development of civilization, which originates in Europe and which spreads in its economic, political and ideological aspects around the world, covering it almost entirely, especially after the World War II" [3]. In other words, this is the "Westernization", meaning "the desire of the West to make other countries similar to itself in social structure, economy, ideology, psychology and culture" [4].

In such circumstances it becomes clear that if we do not have the goal of eliminating all but one civilization, we should take into account not only all the possible positive 
consequences of modernization, but also the hidden threats that this process poses. And the percentage of "positivity" and "negativity" of this process depends on the type or model of modernization that this society will choose for itself. [5]

As a result of the analysis of the development of different states, two main models of modernization can be proposed.

The initiative of modernization can be introduced from the outside, then the model of modernization takes the form known as "Westernization", and can originate within the state, then it is "catch up" modernization.

The first model - Westernization - represents the process of transition from traditional to modern societies by direct transfer of Western values - structures, technologies and lifestyles. This process is carried out with a complete denial of the value of the people's own experience and with a complete change in the spheres of politics, social life, economy and culture.

The lack of willingness and inclination of westernized nations to accept new institutions is not taken into account. The appropriation of natural and human resources is seen as a payment for global values, which, according to Western politicians and ideologists, are the equivalent of material values obtained by the world economy. [6]

The purpose of this process is to bring other countries to such a state that they lose the ability to develop independently, to include them in the sphere of influence of the global economy, and not as equitable and equal partners of the United States and Western Europe, but as satellites or colonies of a new type.

Thus, in accordance with this model, sustainable economic development is provided for westernized nations, but it is achieved through the loss of national and state independence, the solution of the problem of improving the standard of living of the population is performed only for a small part of the population, the economic sphere is developed unilaterally, to the extent in which the "customers" of reforms are interested. [7]

As A.S. Panarin notes, "the subtle inner game of Western culture, consisting in balancing between the austerity of labor and the hedonism of leisure and consumerism, is not detected over a distance. Foreign culture can not pass on its austerity to others, but its external fruits in the form of a high level of consumption, comfort, leisure and entertainment industries are the most communicative" [8]. Criticizing the idea of creating a single civilization, which, after all, is the goal of globalization, Prince N.S. Trubetskoy, more than a century ago, pointed to the hidden desire for leveling and unification of nations under the Roman-German pattern. "They must understand that the culture that was presented to them under the pretext of a universal civilization, is, in fact, the culture of only a certain ethnic group of Roman and German nations" [9].

The second model of modernization is "catch up" one, the decision to carry it out is made within the country. The term "catch-up" modernization can be equally replaced by "imitating" or "borrowing" model.

The essence of the processes of catch-up modernization is industrialization and improvement of human living conditions. The initiative to introduce such reforms usually comes "within" the state, and the form of implementation of the process depends on the level of development of the country, the degree of awareness of the masses of the economic problems that they face, their readiness to solve these problems. This model has the same disadvantages as the first one, as it is almost impossible to "catch up" equally successfully in all directions. But these shortcomings are manifested in a less pronounced form. [10].

The events of the second half of XX - beginning of the XIX century, showed both the disadvantages of catch-up models, and the relevance of the introduction of another model to the modernization theory- "postmodernization", which is modernization as the development on the basis of one's own traditions. The modern example of this type of modernization is given by the countries of South-East Asia, although a prototype of this 
way can be seen when considering the development of a number of European states in the XVIII - XIX centuries, when England was the "modern" state, a role model and the center of the global world order of that time. [11] Taking as a basis the peculiarities of its own economic system and culture and relying on the national mentality, without trying to change it and adjust it to the perception of Western institutions, it was possible to build an institutional system that could compete with the system of the "role model".

At the same time, analysis of the results of functioning of this modernization model shows a slow but steady comprisal by Westernization of countries that chose this model of development, which can be explained by the development of the modernization era to the era of globalization, which spread throughout the world in accordance with its own laws [12].

At this stage of the study it is necessary to understand what the current globalization trends are and whether it is already necessary to talk about the processes of deglobalization. There is an opinion that the desire for autarchy, which has spread through many countries in the last few years, for economic nationalism, the most striking expression of which was the UK's exit from the EU, named "Brexit", represents a general tendency and reversal of world economic policy. In this case, the modernization of national economies should already be adjusted to these new realities. However, everything is explained from the perspective of the cyclical world economic situation. The revival and recovery phases correspond to the desire to benefit from openness and international division of labour, the crisis and depression phases correspond to the desire to close and thus protect the national economy from possible imports of foreign economic problems. [13] Therefore, "deglobalization" should be considered only as a temporary phenomenon, fully consistent with the logic of cyclical economic conditions and general tendencies of globalization of the world economy.

In Russia, modernization, carried out in the period from the end of the XV century to the beginning of the XIX century, is referred to the type of "catch up" modernization by a number of authors [7, 14].

However, the features of the modernization process in Russia, similar to some features of the modernization model of China, Mexico, Japan, give reason to allocate it in a special model - the model of "imperial" modernization. [15]

The imperial model of modernization is "modernization in the name of preserving the military-political status of the empire, for the sake of strengthening military and technical power, which would allow both to resist an attack from the outside, and to support its own expansion" [16, 17]. Changes in economic and social institutions accompanying such a process are only a consequence and serve the best and fastest and most effective achievement of the goal - the goal of creating a powerful military-industrial complex: a strong army equipped with modern weapons, and enterprises working for it. Moreover, only those institutions that hinder the solution of the task are subject to correction, and not necessarily in the direction of "westernization" - democratization. [18,19]

A. Dugin calls the modernization that took place in Russia, "modernization without westernization", because "drawing from time to time upon technological inspiration in Europe, Russia used technologies as a tool, removing them from the cultural context", explaining this situation as "an enduring feature of the national attitude to technologies" [20]. And this, it seems, is the essence, peculiarity and difference of all modernization processes observed in the history of Russia for almost six hundred years.

Each of these models (except imperial modernization) implies the liberalization of national economies and political systems, which should be accompanied by the assimilation of the "Western way of life". That is, all that is commonly called informal institutions of society, which include national as well as economic institutions, mentality. 


\section{Conclusions}

Thus, taking into account the long-term tendencies of globalization of the world economy, we can distinguish three alternative strategies for Russia's development.

First, having achieved the easing of the sanctions regime, to seek to integrate into the system of international division of labour and to follow the globalization patterns, joining the individualistic, commercial ideals of the United States and Western Europe, which the supporters of Westernization try to achieve.

Second, to borrow the existing institutions of economic and social-political life from Western civilization, trying to combine them with Russian realities.

Third, to move to a new concept of sustainable development - the national formula of modernization, setting clear rules for its implementation. For this purpose it is necessary to revise foreign experience taking into account all mistakes and costs, to choose acceptable forms of social and economic life, regarding centuries-old norms and traditions of economic and cultural life of Russia. These norms and traditions, integrating with selected elements of the Western institutional environment, should create conditions for the revival of all spheres of life, and the national mentality should preserve its specificity even in modernized forms.

\section{References}

1. F. J. Bierbrauer, P.C. Boyer. Efficiency, Welfare, and Political Competition. The Quarterly Journal of Economics, 131(1), 461-518 (2016)

2. P. J. Buhanan. Smert Zapada [Death of the West]. Moscow. (2004).

3. S. N. Eisenstodt. Patterns of Modernity, Ed. By S.N.Eisenstodt. N.Y. Introduction: Historical Traditions, Modernization and Development., (1). The West, 5. Quote from the book Modernization. Foreign experience and Russia. Moscow. (1994).

4. A. A. Zinoviev. Zapad. Fenomen zapadnizma [West. Phenomenon of westernism]. Moscow. (1995).

5. F. Boffa, A. Piolatto, A. Giacomo. Ponzetto Political Centralization and Government Accountability. The Quarterly Journal of Economics, 131(1), 381-422 (2016)

6. D. Berger, V. Guerrieri, G. Lorenzoni, J. Vavra. House Prices and Consumer Spending. The Review of Economic Studies, 85(3), 1502-1542 (2018)

7. P. Martin, T. Mayer, M. Thoenig. Make Trade Not War? The Review of Economic Studies, 75(3), 865-900 (2008)

8. Bulletin of Russian Academy of sciences. Sotsialnaya modernizatsiya Rossii: Materialy obsuzhdeniya za "kruglym stolom" v Institute filosofii RAN [Social modernization of Russia: Information for discussion at a "round table" in Philosophy Institute of RAS] V.63. 3. (1993).

9. N.S. Trubetskoy. Evropa i tchelovechestvo. Istoriya. Nauka. Yazyk [Europe and humanity. History. Science. Language] - Moscow. (1995).

10. F. Armin, A. Becker, T. Dohmen, B. Enke, D. Huffman. Uwe Sunde Global Evidence on Economic Preferences. The Quarterly Journal of Economics, 133(4), 1645-1692 (2018)

11. S. Guthmuller, F. Jusot, J. Wittwer. Improving Takeup of Health Insurance Program: A Social Experiment in France. Journal of Human Resources, 167-194 (2014)

12. M.K. Chan, Welfare Dependence and Self-Control: An Empirical Analysis. The Review of Economic Studies, 84(4) 1379-1423 (2014) 
13. C. N. Noussair, S. T. Trautmann, G. Van de Kuilen. Higher Order Risk Attitudes, Demographics, and Financial Decisions. The Review of Economic Studies, 81(1), 325355 (2014)

14. V. T. Ryazanov. Russian economic journal. Reformy i tsikly modernizatsii rossiiskoy ekonomiki. Reforms and cycles of modernization of Russian economy, 10. (1992)

15. G. Padró i Miquel. The Control of Politicians in Divided Societies: The Politics of Fear. The Review of Economic Studies, 74(4), 1259-1274 (2007)

16. V. A. Krasilschikov. Vdogonku za proshedshim vekom. Razvitiye Rossii v XX veke s tochki zreniya mirovykh modernizatsiy. In pursuit of the previous century. Development of Russia in the XX century from the viewpoints of world modernizations, Moscow (1998)

17. V. G. Horos. Russkaya istoriya v sravnitelnom osveschenii. Russian history in comparative coverage, Moscow (1996)

18. B. Fernando, V. Jaume. Rethinking the Effects of Financial Globalization. The Quarterly Journal of Economics, 131(3), 1497-1542 (2016)

19. M. Nadanyiova, The Possibility of Introducing the CRM System in Railway Company Cargo Slovakia. In 17th International Conference on Transport Means (Kaunas, Lithuania, 87-92, 2013)

20. A. Dugin. Evraziyskiy put' kak natsionalnaya ideya. Eurasian way as a national idea, Moscow (2002) 